UDC $598.2(477.41 / 42)$

\title{
ECOLOGICAL SEGREGATION OF THRUSHES OF GENUS TURDUS IN TERMS OF VOLYN POLISSIA
}

\author{
M. V. Franchuk', V. M. Peskov', M. O. Tarasenko ${ }^{3}$ \\ ${ }^{1}$ Rivne Nature Reserve, natural object "Dubky-Rozvylka", Sarny, Rivne Region, 34500, Ukraine \\ ${ }^{2}$ Schmalhausen Institute of Zoology, NAS of Ukraine, 15, B. Khmelnytskyi St., Kyiv 01601, Ukraine \\ ${ }^{3}$ Kamyanets-Podilsky Ivan Ohienko National University, \\ Kamyanets-Podilsky, Khmelnytsky Region, 32300, Ukraine \\ e-mail: m_franchuk@ukr.net
}

An ecological segregation of five species of thrushes (Turdus pilaris, T. merula, T. iliacus, T. philomelos, T. viscivorus) in Volyn Polissia was studied. For the overwhelming majority of ecological characteristics, the most similar are Song Thrush and Blackbird $(\mathrm{DE}=38.36)$. They have similar biotopical preferences in forest and forest edges habitats, almost the same nesting height (1.58 and $2.00 \mathrm{~m}$, accordingly), similar feed rations. All this gives us the reason to conclude minimal ecological segregation of Song Thrush and Blackbird in the forest ecosystems of Volyn Polissia. At the same time, they avoid high ecological competition due to different ratios in thrushes complexes in the certain territories [22, 23], structure of nesting habitats [23]. Fieldfare often settled near open habitats by meadows and forest edges, build the nests on the prevailing tree species within the habitat. Food preferences associated primarily with the composition of the feed, the majority of which is produced out of the forest habitats. Mistle Thrush prefers medieval pine forests without undergrowth (73\% of all habitats) with poor forest floor, that made different strategy of food use and obtaining among all presented thrushes species. It was established that among the five studied species of thrushes Redwing and Mistle Thrush has the highest value of ecological specialization and segregation.

Keywords: Thrushes, ecological segregation, interspecific differences, Volyn Polissia.

\section{INTRODUCTION}

In Volyn Polissia, avifauna of genus Turdus is represented by five species: Turdus pilaris (Fieldfare), T. merula (Common Blackbird), T. iliacus (Redwing), T. philomelos (Song Thrush) and T. viscivorus (Mistle Thrush). Various aspects of the biology and ecology of these species are well explored at this time. At the same time the question of environmental differences, the competitive relationship in terms of the coexistence of these species in forest ecosystems Volyn Polissia remained still open [2, 28]. In addition, the ecological specialization and segregation of closely related species of birds,

ISSN 1996-4536 (print) • ISSN 2311-0783 (on-line) • Біологічні Студії / Studia Biologica • 2016 • Том 10/№1 • С. 89-98 
that inhabit sympatrical in particular ecosystems is still actual, what helps to understand the principles of distribution of ecological resources, development of lifestyle and the place and role of each species in the appropriate grouping [17, 22].

Mentioned Turdus species shared mutual environmental resources within their nesting range, particularly in conditions of Volyn Polissia forest ecosystems, so studying of their ecological specialization and segregation are important for the understanding of place, role and weight of each species as a structural element of a particular ecosystem. Therefore, we tried to investigate basic ecological mechanisms of thrushes coexistence and estimate the range and the character of their ecological segregation in Volyn Polissia.

\section{MATERIALS AND METHODS}

Materials of thrushes breeding ecology of Volyn Polissia were collected in AprilJuly 2007-2015. Much of the data are taken from West-Ukrainian Ornithological Society data base of nests and clutches of the birds collected within the studied region during the 1984-2006.

Research of biotopical preferences performed relatively to the breeding habitat what recorded for each founded nest. Totally 11 habitats were found (coastal scrubs, roadways shelterbelts, deciduous woodlands, mixed forests, older forest plantations, middle-aged pine plantations, middle-aged spruce plantations, young-aged pine plantations, parks, orchards, black chokeberry plantations). For comparison, Thrushes trophic preferences used published data [2, 5, 6, 11, 12, 19, 25, 26, 30-32].

In a field, we described the height of nest placing, measured from the ground $(L)$, and species of tree or shrub for each found Thrushes nest.

Analysis of the results was performed with standard statistical methods. Statistical calculation was made in Microsof Office Excel 2007 and "11.0 Statistics" programs.

\section{RESULTS AND DISCUSSION}

The Fieldfare, Blackbird and Song Thrush are common breeding $[4,12,14-16,29-$ 32], occasionally wintering [7, 8, 15] species at the study area. Instead, Mistle Thrush and Redwing are rare range-boundary species here $[12,15,29]$.

Biotopical distribution. Nesting of few thrushes species within the mutual habitat is normal [2, 22], but the rate of each species in ornithocenozis is different.

The mixed forests biotopes are distinctive for Redwing ( $83.3 \%$ of nests) and less for Blackbird (30.6\%) and Song Thrush (29.0\%). Mistle Thrush for nesting prefers green-moss-blueberry middle-aged pine biotopes without undergrowth $(73.0 \%$ of nests detected in all types of habitats). Instead Fieldfare (14.6\%), Blackbird $(13.8 \%)$ and Song Thrush (15.6\%) nest in such biotope in small quantities. Important role for nesting of thrushes play a young pine plantation under 20 - the rate of detected nests are high for Redwing (16.7 \%), Song Thrush (15.2\%) and for Fieldfare (15.4 \%). The last one prefers shelterbelts along roadways and railways (36.2 \%) and coastal willow growth $(10.8 \%)$. Important role for nesting of thrushes in Volyn Polissia play deciduous forests formed with alder (Alnus glutinosa), silver birch (Betula pendula), English oak (Quercus robur) and aspen (Populus tremula), where found a significant rate of nests of Song Thrush (19.,3\%) and Blackbird (15.0\%). Over-moist black-alder forests with dense undergrowth play a slight role in nesting of Blackbird (11.9\%), Mistle Thrush $(7.7 \%)$ and Fieldfares (6.2\%).

ISSN 1996-4536 (print) • ISSN 2311-0783 (on-line) • Біологічні Студії / Studia Biologica • 2016 • Том 10/№1 • С. 89-98 
The main priority in the selection of the nesting habitat for thrushes has the quality of feed $[2,5,6]$. The basis of thrushes feed compose the ground oligochaetes, whose quantity depends on moisture conditions of the biotope [5]. The trees and shrubs architectonic $[10,11,20,27]$ and habitat structure (close allocation of forest edges, water or open spaces) $[3,14,22]$ are also have an important role for nest disposition.

Cluster analysis shows (Fig. 1) that habitat distribution of Blackbird and Song Thrush is most similar $(D E=11.27)$, some differs Fieldfare $(D E=42.77-79.63)$ and Redwing (DE = 59.0-60.4). Habitat distribution of Mistle Thrush significantly differs from those Blackbird and Song Thrush (DE = 67.9-68.19) but higher differences detected between Mistle Thrush and Redwing (DE = 104.26).

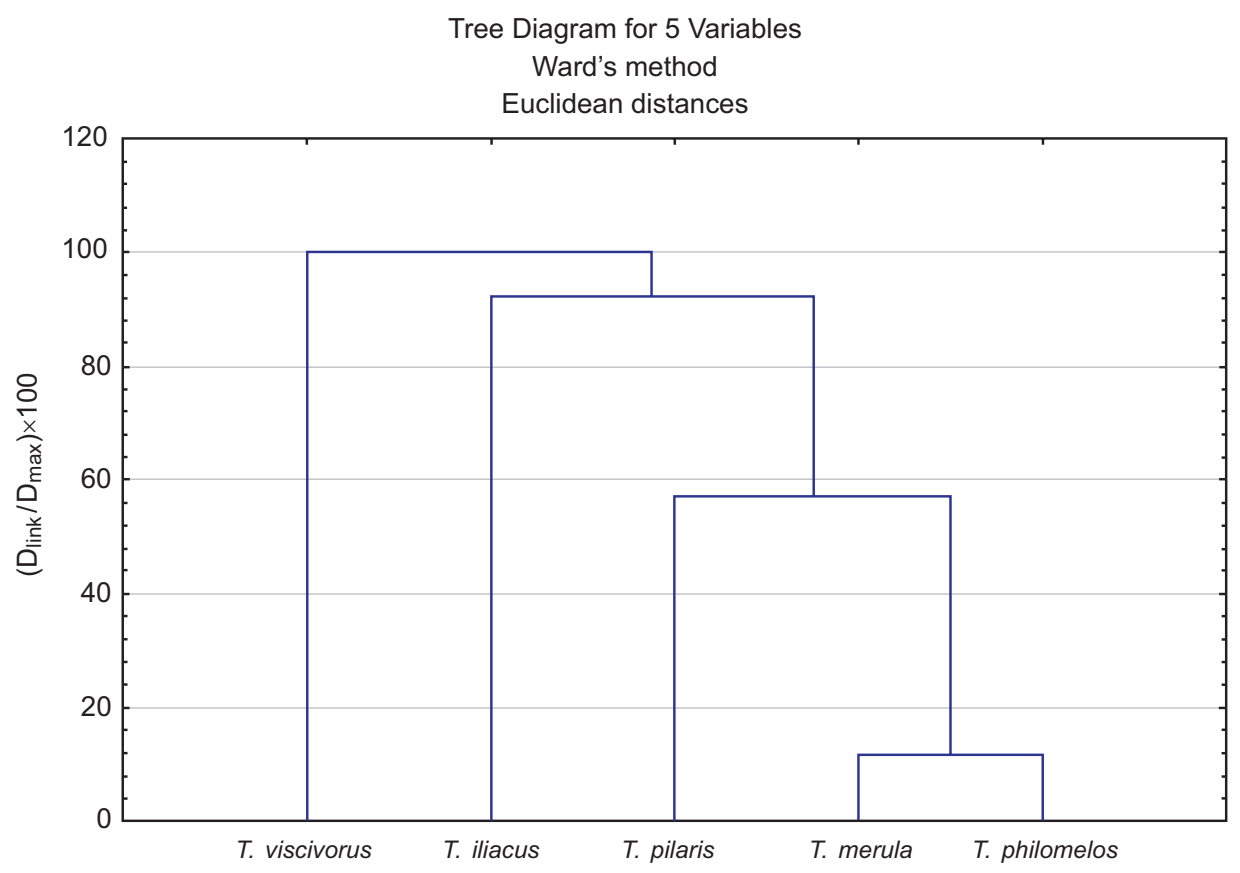

Fig. 1. Cluster analysis of the similarity of Turdus species by habitat distribution

Рис. 1. Кластерний аналіз подібності представників роду Turdus за біотопічним розподілом

Spatial placement of nests. Established that thrushes in Volyn Polissia use 38 species of trees and shrubs $(n=560)$ for building nests. According to our data four species prefer trees $(50.0 \%$ of Redwings, $75.7 \%$ of Song Thrushes, $78.3 \%$ of Blackbirds, $92.9 \%$ of Mistle Thrushes and $96.1 \%$ of Fieldfares nests were build on trees). The rate of nests, located on bushes is $7.1-33.0 \%$ on another substrate - is negligible.

The distribution of nests by species of trees and shrubs in Volyn Polissia is heterogeneous. Thrushes often used conifers (Pinus sylvestris, Picea abies, Pinus banksiana) and shrubs (Juniperus communis), which is also typical for other parts of the European range, particularly in Polissian and central parts of Poland [12, 13, 33].

We found that the rate of Mistle Thrushes nests located on the pine is $71.4 \%$, for Song Thrush $-34.4 \%$, Fieldfares $-28.7 \%$ and Blackbird $-24.3 \%$. On the spruce we found $11.6 \%$ Song Thrushes, $7.9 \%$ of Blackbird, $7.1 \%$ of Mistle Thrushes nests. Re-

ISSN 1996-4536 (print) • ISSN 2311-0783 (on-line) • Біологічні Студії / Studia Biologica • 2016 • Том 10/№1 • С. 89-98 
markable that Fieldfares and Redwings nests on spruce wasn't found. $7.1 \%$ of Mistle Thrush nests we found on Jack pine, which was introduced in the region in 1970-1990. The rate of nests detected on juniper is $17.7 \%$ for the Song Thrush, $16.7 \%$ for Redwing, $8.6 \%$ for Blackbird, $7.1 \%$ for Mistle Thrush and $2.3 \%$ for Fieldfare. Choice the conifer as nesting tree for thrushes has a similar trend in mixed forest of Russia, Belarus, Ukraine and taiga $[1,4,6,14,18,21,32]$ and especially for Ukrainian Steppe zone [9]. According A.B. Chaplygina, evergreen conifer plantations create favorable conditions for placing and disguising of thrushes nests [10].

Significant role for nest disposition have the deciduous tree species also. Thus, the Blackbird placed his nests on black alder in $24.3 \%$, Song Thrush - in $6.2 \%$, Fieldfare in $5.4 \%$. The last one build nests mainly on Populus nigra var. pyramidalis $(23.3 \%)$ and ash $(10.9 \%)$, which form monotypic roadways shelterbelts. The rate of other deciduous trees species for thrushes nest disposition is negligible. Placing nest on a particular tree species primarily depends on the nesting sites (habitats), species composition and suitable conditions for placing and disguising of nests.

As a result of cluster analysis (Fig. 2), the most similar in trees and bushes species composition for nesting are Fieldfare and Song Thrush $(D E=23.84)$, slightly more differs Blackbird, Song Thrush and Fieldfare (DE = 33.75-35.47). Apart from other species are Redwing (DE = 43.96-62.0) and Mistle Thrush (DE = 41.33-91.65).

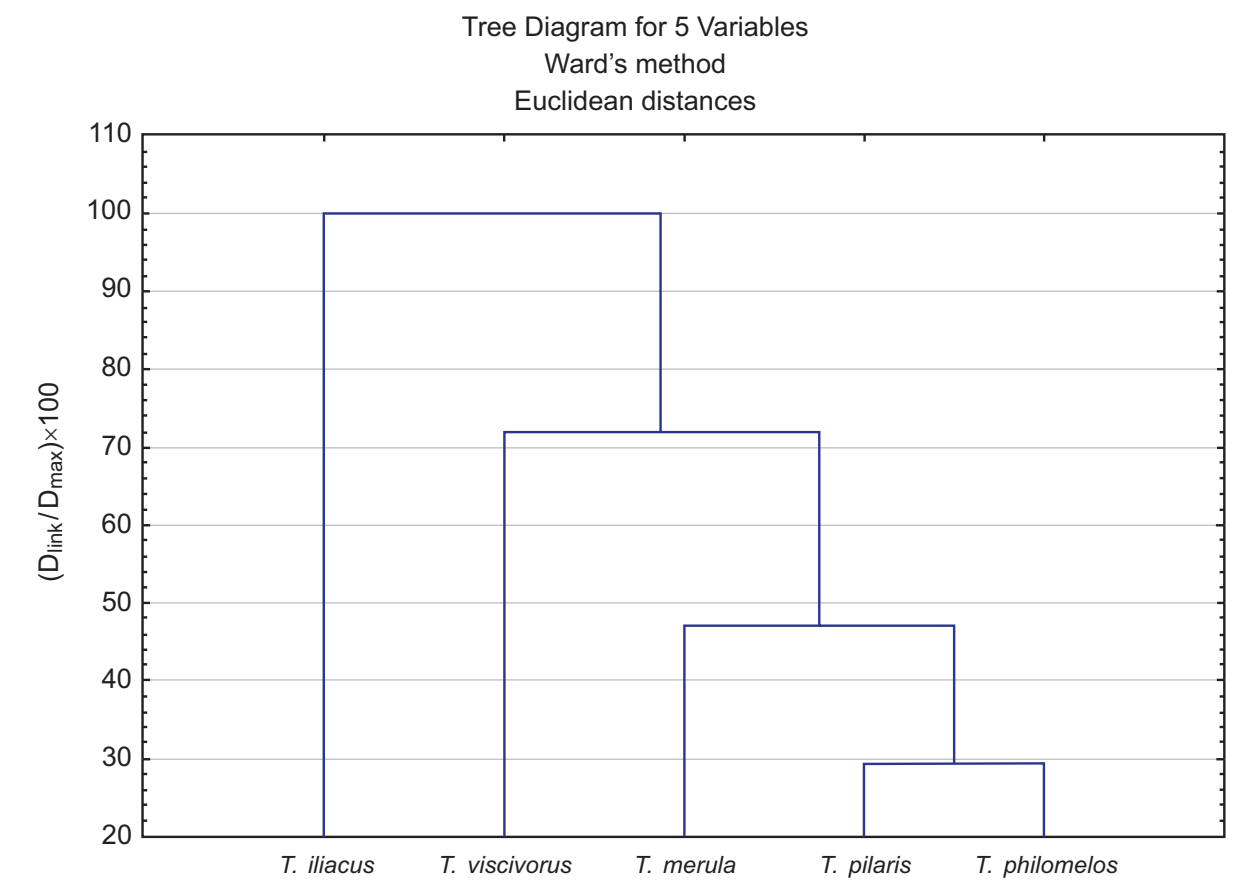

Fig. 2. Cluster analysis of the similarity of Turdus species by nesting trees

Рис. 2. Кластерний аналіз подібності представників роду Turdus за породним складом дерев, на яких розміщені гнізда

The average height of the nest allocation smallest for Redwing $(n=6 ; 0.86 \pm 0,43 \mathrm{~m}$; $\lim 0.2-2.5 \mathrm{~m})$, slightly higher build nests Song Thrush $(\mathrm{n}=215 ; 1.58 \pm 0,10 ; \lim 0.1-6.0 \mathrm{~m})$, 
Blackbird ( $n=139 ; 2.0 \pm 0,06$; lim 0,1-6,0 m) and Mistle Thrush $(n=14 ; 2.98 \pm 0.38$ m; lim $1.3-7.0 \mathrm{~m})$. The highest average height of the nest allocation detected for Fieldfare ( $\mathrm{n}=118 ; 5.2 \pm 0.14 \mathrm{~m}$; lim 0.5-11.0 m).

Feeding of adults and nestlings. On the results of the literature analysis for neighboring to Volyn Polissia areas [19, 26, 30-32] and within the thrushes European range $[2,5,12,25]$, the specifics of nutrition has not significant differences, however, has significant interspecific differences [2, 6, 24]. According to A.V. Baranovsky with colleagues [2], the character of food extraction and feature of foraging behavior formed various ecological, morphological, physiological, ethological and other adaptations which became the basis of formation of ecological differences. So, detected that highest rate of similarity is peculiar to the Song Thrush and Blackbird, the lowest - in Song Thrush and Fieldfare, an intermediate position occupies Fieldfare and Redwing, at the same time Mistle Thrush is the most remote of the four other Turdus species. The explanation for this difference is in the variety of species feeding preferences - Redwing use larger prey then Blackbird, Song Thrush or Fieldfare; Song Thrush have the strict feeding preference of three types of prey - earthworms, caterpillars and mollusks, while the Blackbird haven't any feeding preference [11]. The last two mentioned species feeds mainly on the forest floor and on the surface of the substrate, but differs is foraging strategy [31,32]. Mistle Thrush has significant differences from others thrushes species - in his diet almost no earthworms, preferred prey of medium and large size (for example, observed cases of hunting newts and lizards), most likes eat beetles, caterpillars of owlet moth, feeds in various places mainly on a ground [25].

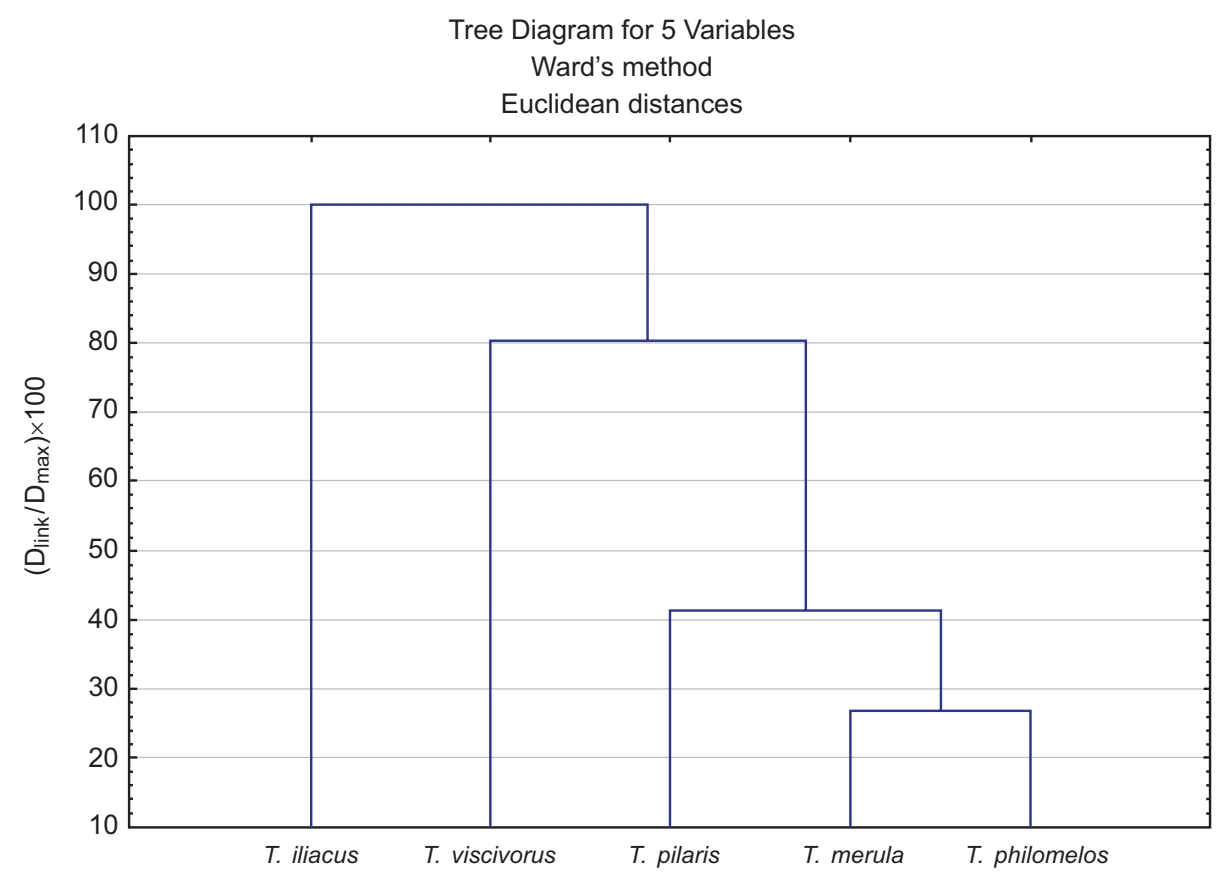

Fig. 3. Structure of the similarity of Turdus genus by DE aggregated values

Рис. 3. Структура подібності представників роду Turdus за узагальненими значеннями DE

ISSN 1996-4536 (print) • ISSN 2311-0783 (on-line) • Біологічні Студії / Studia Biologica • 2016 • Том 10/№1 • C. 89-98 
Despite the great similarity in feeding, trophic competition in thrushes not appear or have slight value [23]. According to A.B. Chaplygina, interspecific similarity in feeding caused by overlapping of the trophic niches [9].

In a result of cluster analysis (Fig. 3), it was revealed that most ecologically similar are Blackbird and Song Thrush (DE = 38.36). The Fieldfare is also close to them $(\mathrm{DE}=52.92$ and $\mathrm{DE}=55.65$, accordingly). From these three species considerably vary Redwing and Mistle Thrush (Fig. 3). Remarkably that Fieldfare and Mistle Thrush most differ from the Redwing with DE values 122.7 and 160.0 , respectively.

\section{CONCLUSIONS}

In a result of the comparison of five studied thrushes species by major ecological performance, the following conclusions of their ecological specialization and segregation are formed. For the overwhelming majority of ecological characteristics the most similar Song Thrush and Blackbird (DE = 38.36). They have the similar biotopical preferences because prefer forest habitats and forest edges, nesting almost on the same height (1.58 and $2.00 \mathrm{~m}$, accordingly) and have the similar feed rations. All this gives us the reason to conclude that ecological segregation of Song Thrush and Blackbird in the forest ecosystems of Volyn Polissia is minimal. At the same time, they avoid high ecological competition due to different ratios in thrushes complexes in the certain areas [22, 23] and structure of nesting habitats [23]. Fieldfare often settled near open habitats along the meadows and forest edges, they build the nests on the prevailing tree species within the habitat. Food preferences were associated primarily with the composition of the feed, the main part of which is obtained out of forest habitats. Mistle Thrush prefers medieval pine forest with no undergrowth (73\% of all habitats) with poor forest floor, what became the reason of feed composition and foraging strategy differences from the other thrushes species. This all leads to a conclusion that among five studied species of thrushes Redwing and Mistle Thrush has the highest value of ecological specialization and segregation.

\section{ACKNOWLEDGEMENTS}

The authors are grateful to A.A. Bokotey, I.M. Gorban, O.S. Hnatyna, V.I. Shkaran, I.V. Shydlovskyy for the opportunity to use the West-Ukrainian Ornithological Society data base of nests and clutches of the birds and separate to R.O. Zhuravchak, A.V. Dobrinskyy for help in preparing of this article.

ISSN 1996-4536 (print) • ISSN 2311-0783 (on-line) • Біологічні Студії / Studia Biologica • 2016 • Том 10/№1 • С. 89-98 
1. Alexandrova I.V. Thrushes of Pryoksko-Terrasny natural reserve. Proceedings of the III conference of the Baltic ornithology. Vilnius, 1959: 3-12. (In Russian).

2. Baranovsky A.V., Khlebosolov E.I., Sorokina E.A. et al. Mechanisms of ecological segregation four co-inhabiting species of Thrushes Fieldfare T. pilaris, Redwing T. iliacus, Song Thrush T. philomelos and Blackbird T. merula. Russian Ornithol. Journal, 2007;16 (377): 1219-1230. (In Russian).

3. Barnard C.J., Stepheus H. Cost and benefits single flocking in Fieldfare (Turdus pilaris) and Redwings (Turdus iliacus). Behavior, 1983; 84: 91-123.

4. Bokotey A.A., Gorban I.M., Kostyushin V.A., Fessenko H.V. The Fieldfare nesting in the natural habitats and urban landscapes of the Western Ukraine. Berkut, 1994; 3 (1): 22-26. (In Ukrainian).

5. Brovkina E.T. Materials of feeding and forestry value of Thrushes in the Moscow region. Proceedings of the III conference of the Baltic ornithology. Vilnius, 1957: 31-40. (In Russian).

6. Brovkina E.T. Materials of breeding biology of Thrushes. Scientists papers MHPU, 1959; 104 (8): 227-257. (In Russian).

7. Catalogue of bird fauna of the Western regions of Ukraine. Avifaunistic observations during 1989-1990. Troglodytes: Works of WUOS. Lutsk, 1994; 2: 46, 83-84. (In Ukrainian).

8. Catalogue of bird fauna of the Western regions of Ukraine. Avifaunistic observations during 1993. Troglodytes: Works of WUOS. Lviv, 1994: 9, 26. (In Ukrainian).

9. Chaplygina A.B. Biogeocenotic adaptation and population of birds in transformed landscapes in North-Eastern Ukraine (for example genus Turdus): 03.00.16. Abstract of dissertation for the PhD degree. Dnipropetrovsk, 1998: 1-24. (In Ukrainian).

10. Chaplygina A.B. Patterns of nest location of Thrushes of the genus Turdus in transformed landscapes of North-East Ukraine. Berkut, 2009; 18(1-2): 135-142. (In Ukrainian)

11. Cherenkov S.E., Hubenko I.Y., Tiunov A.V., Kuzmichev A.Y. Factors determining the spatial structure of settlements of Thrushes (Turdus) in high forest mosaic. Russian Ornithol. Journal, 1995; 74(2): 104-119. (In Russian).

12. Cramp S. The birds of the Western Palearctic. Tyrans flycatches of Trushes: hendbook of the birds of Europe the Middle East and Noth Africa. Oxford, New York: Oxford University, 1988; 5: 949-1011.

13. Dyrcz A. Ecology of the Song Thrush (Turdus philomelos) and Blackbird (Turdus merula) during the breeding season in an area of their occurrence. Ekologia Polska, 1969; 17 (39): 735-793.

14. Franchuk M. To the nestling biology of Song Thrush (Turdus philomelos, L. Brehm, 1831) in nature protection territories of Western Ukrainian Polissia. Visnyk of Lviv Univ.: Biology series, 2013; 62: 234-241. (In Ukrainian).

15. Franchuk M.V., Bokotey A.A. To breeding biology of Mistle Thrush (Turdus viscivorus L.) and Redwing in (Turdus iliacus L.) in the Western Polissia. Studia Biologica, 2014; 8 (3-4); 169-178. (In Ukrainian).

16. Kovalenko A.F., Fesenko H.V. Peculiarities of nesting of Fieldfare in the South of Volyn' region. In the book.: Bird fauna of the Western regions of Ukraine and the problems of its protection: Materials of the report 5 of the meeting of ornithologists and amateurs of ornithological movement of Ukraine. Luts'k: Publishing department of Volyn' regional publishing house, 1990: 21-26. (In Ukrainian).

17. Kreslavskii A.G. Sympatric speciation in animals: distruptive selection or ecological segregation. Journal of General Biology, 1994; 55(4-5): 404-419. (In Russian).

18. Malczewski A.S., Pukinsky J.B. Birds of the Leningrad region and adjacent territories. History, biology, conservation. Leningrad: Leningrad university publishing, 1983; 2: 1-504. (In Russian). 
19. Marysova I.V. Materials for the study of nutrition and practical values Thrushes of Ukraine. Materials conf. "The study of natural resources Podillya". Ternopil, 1963: 152-157. (In Ukrainian).

20. Nankinov D.N. Studies on the breeding ecology of Song Thrush Turdus philomelos. Larus, 1977; 29-30: 159-170. (In Russian).

21. Nikiforov N.Y., Yaminsky B.V., Shkliarov L.K. Birds of Belarus. Minsk: High school, 1989: 376-386. (In Russian).

22. Piskunov V.V., Davidenko T.N. Habitat structure types and stability of the spatial organization of Song Thrush and Blackbird individual territories. Proceedings of the Samara Scientific Center of the RAS, 2009; 11(1): 96-101. (In Russian).

23. Priezzhev G.P. About interspecies relationships have Thrushes. Materials of Scientific Conference of Zoologists of Pedagogical Universities. Gorky, 1970: 380-382. (In Russian).

24. Prokofieva I.V. To feeding chicks Mistle Thrush Turdus viscivorus and Blackbird Turdus merula in the South of Leningrad region. Russian Ornithol. Journal, 2003; 340: 423-444. (In Russian).

25. Prokofieva I.V. Comparison of feeding Mistle Thrush Turdus viscivorus in different areas, the others' very distant from each other. Russian Ornithol. Journal, 2007; 340: 45-49. (In Russian).

26. Rizun E.M. On the relationship between the Fieldfare and Common Blackbird (Turdus pilaris L., Turdus merula L.) number and number of their feeding objects. Scientific Bulletin of UNFU. Lviv, 2010; 20 (15): 42-47. (In Ukrainian).

27. Sahvon V.V. Biogeocenosis structure of riparian forests as a factor, defining certain aspects breeding biology of birds (an example of the genus Turdus). Vestnik BSU, 2009; 2(2); 5963. (In Russian).

28. Shukshina M.S. Mechanisms of ecological segregation Blackbird and Fieldfare in Kaliningrad. Theses XIV International Ornithological Conference of Northern Eurasia: Almaty, 2015: 551-552. (In Russian).

29. Stepanian L.S. Synopsis of ornithological fauna of the USSR. Moscow: Science, 1990. 332 p. (In Russian).

30. Talposh V.S. Fieldfare in the Western regions of Ukraine. Berkut, 1996; 5(2): 152-157. (In Russian).

31. Talposh V.S. To the ecology of Blackbird in Podillia region. Berkut, 1998; 7(1-2): 64-69. (In Russian)

32. Talposh V.S. Song Thrush in the Western Ukraine. Berkut, 1999; 8(1): 78-88. (In Ukrainian).

33. Wesołowski T., Czapulak A. Biologia rozrodu kosa (Turdus merula) i drozda śpievaka (Turdus philomelos) w Polsce - wstępna analiza kart gniazdowych. Notatki Ornitologiczne, 1986; 27(1-2): 32-60.

ISSN 1996-4536 (print) • ISSN 2311-0783 (on-line) • Біологічні Студії / Studia Biologica • 2016 • Том 10/№1 • С. 89-98 


\title{
ЕКОЛОГІЧНА СЕГРЕГАЦІЯ ДРОЗДІВ РОДУ TURDUS В УМОВАХ вОЛИНСЬКОГО ПОЛІССЯ
}

\author{
М. В. Франчук', В. М. Пєсков ${ }^{2}$, М. О. Тарасенко \\ ${ }^{1}$ Рівненський природний заповідник, урочище “Дубки-Розвилка" \\ Сарни, Рівненська область 34500, Україна \\ ${ }^{2}$ /нститут зоології ім. І. Шмальгаузена НАН України \\ вул. Б. Хмельницького, 15, Київ 01601, Україна \\ ${ }^{3}$ Кам'янець-Подільський національний університет ім. І. Огієнка, Кам'янець-Подільський \\ Хмельницька область 32300, Україна \\ e-mail: m_franchuk@ukr.net
}

Проведено дослідження екологічної сегрегації п'яти видів дроздів (Turdus pilaris, T. merula, T. iliacus, T. philomelos, T. viscivorus) в умовах Волинського Полісся. За переважною більшістю екологічних характеристик найбільш подібними виявилися дрозди співочий і чорний. (DE = 38,36). Вони мають подібні біотопічні преференції, тому що віддають перевагу лісовим біотопам та узліссю, гніздяться практично на одній висоті (1,58 і 2,00 м відповідно), мають схожі кормові раціони. Це дає підстави вважати, що екологічна сегрегація співочого і чорного дроздів у лісових екосистемах Західного Полісся мінімальна. Водночас вони уникають високої екологічної конкуренції завдяки різному співвідношенню за чисельністю у складі угруповань дроздів на тих чи інших територіях [12, 35], структурою гніздових стацій [35]. Чикотень найчастіше поселяється поблизу відкритих біотопів лук і на узліссі, розміщує гнізда на переважаючій породі в межах біотопу. Кормові преференції пов'язані насамперед зі складом корму, левову частку якої добувають за межами лісових біотопів. Дріздомелюх віддає перевагу середньовіковим сосновим масивам без підліску (73 \% від усіх біотопів) із бідною підстилкою, що зумовило відмінну від усіх представлених видів дроздів специфіку використання кормів і стратегії їх добування. Встановлено, що серед п'яти досліджених видів дроздів найбільший рівень екологічної спеціалізації та, відповідно, сегрегації мають дрізд білобровий і дрізд-омелюх.

Ключові слова: дрозди, екологічна сегрегація, міжвидові відмінності, Волинське Полісся.

\section{ЭКОЛОГИЧЕСКАЯ СЕГРЕГАЦИЯ ДРОЗДОВ РОДА TURDUS В УСЛОВИЯХ ВОЛЫНСКОГО ПОЛЕСЬЯ}

\author{
М. В. Франчук', В. М. Песков ${ }^{2}$, М. О. Тарасенко \\ ${ }^{1}$ Ровенский природный заповедник, ур. “Дубки-Развилка” \\ Сарны, Ровенская область, 34500, Украина \\ ${ }^{2}$ Институт зоологии им. И. Шмальгаузена НАН Украины \\ ул. Б. Хмельницкого, 15, Киев 01601, Украина \\ ${ }^{3}$ Каменец-Подольський национальный университет им. И. Огиенко \\ Каменец-Подольский, Хмельницкая область 32300, Украина \\ e-mail: m_franchuk@ukr.net
}

Проведено исследование экологической сегрегации пяти видов дроздов (Turdus pilaris, T. merula, T. iliacus, T. philomelos, T. viscivorus) в условиях Волынско- 
го Полесья. По подавляющему большинству экологических характеристик наиболее похожими оказались дрозды певчий и черный (DE = 38,36). Они имеют похожие биотопические преференции, так как предпочитают гнездиться в лесных биотопах и на опушке леса, гнездятся практически на одной высоте (1,58 и 2,00 м, соответственно), имеют похожие кормовые рационы. Это дает основания считать, что экологическая сегрегация певчего и черного дроздов в лесных экосистемах Волынского Полесья минимальна. В то же время они избегают высокой экологической конкуренции благодаря разному соотношению по численности в составе сообщест дроздов на тех или иных территориях $[12,35]$, структуре гнездовых стаций [35]. Рябинник чаще селится вблизи открытых биотопов вдоль лугов и на опушке леса, размещает гнезда на преобладающей породе в пределах биотопа. Кормовые преференции связаны в первую очередь с составом корма, львиная доля которой добывается в не лесных биотопов. Деряба предпочитает средневозрастные сосновые массивы без подлеска (73 \% от всех биотопов) с бедной подстилкой, что обусловило отличающуюся от всех представленных видов дроздов специфику использования кормов и стратегии их добычи. Установлено, что среди пяти исследованных видов дроздов наибольший уровень экологической специализации и, соответственно, сегрегации имеют белобровник и деряба.

Ключевые слова: дрозды, экологическая сегрегация, межвидовые различия, Волынское Полесье.

Одержано: 28.12.2015

ISSN 1996-4536 (print) • ISSN 2311-0783 (on-line) • Біологічні Студії / Studia Biologica • 2016 • Том 10/№1 • С. 89-98 